Article

\title{
Planting the Seeds of the Future: Eschatological Environmentalism in the Time of the Anthropocene
}

\author{
Paolo Bocci 1
}

Thompson Writing Program, Duke University, Durham, NC 27708, USA; paolo.bocci@gmail.com

Received: 2 December 2018; Accepted: 18 February 2019; Published: 20 February 2019

\begin{abstract}
Drawing on ethnographic fieldwork, this essay examines how the local Jehovah's Witnesses' response to the current ecological crisis on the Galápagos Islands has produced a distinct form of religious environmentalism. Specifically, I argue that the Jehovah's Witnesses' vision of the ultimate future informs action rather than despair-contrary to what is often assumed about millenarian beliefs. This essay joins voices in Christian feminist and eco-theology interested in reclaiming eschatology for its imaginative valence. Yet, unlike invocations for hope that lack consideration of their viability, my ethnographic approach contributes to this literature with a view of the practical reverberations of eschatology. Further, current discussions about ecological unraveling, often couched around the concept of the Anthropocene, have reinforced expert-driven, techno-scientific measures that exclude other forms of knowledge production and practical interventions. If such worries continue to motivate a paradigm of conservation that exclude locals, my essay shows how the local Jehovah's Witnesses promote a valuable alternative form of environmentalism, on the Galápagos and elsewhere.
\end{abstract}

Keywords: eco-theology; endemic plants; invasive species; urbanization; the Anthropocene; conservation; environmental anthropology; the Galápagos Islands; Ecuador

\section{Introduction: The Fate and Faith of the World}

Since the 1990s, the field of religion and ecology has investigated the role of religion in shaping people's relationship with the environment and, with increasing urgency, their understanding of and responses to the global environmental crisis. Within this field, claims that religions can produce stewardship to better address climate change have multiplied over the years (Grim and Tucker 2014; Jenkins 2013; Mickey 2015; Palmer and Finlay 2003)—but so, too, have critiques. I group these critiques under three broad categories and illustrate each with a case study. First, environmentally friendly doctrines often coexist with contrasting messages within the same religion. In her analysis of climate change denial in the United States, Marisa Ronan argues that dominionism, the precept of humanity's duty to "fill and subdue the earth," has rendered many US evangelical congregations refractory to calls for environmental awareness, even those originating within evangelical groups (Ronan 2017). Second, scholars have pointed to the uncritical, ahistorical nature of the claim about religion's capacity for environmentalism. Notermans, Nugteren, and Sunny, by demonstrating how Hindu rituals promote the destruction of "sacred groves" in the district of Kerala, India, call for situated claims and caution against abstract invocations of religion's role in informing environmentalism (Notermans et al. 2016). Third, while many religions may give normative value to protecting the environment, their rituals and doctrines are seldom in close dialogue with natural events and processes unfolding on the Earth. Reflecting critically on Catholicism's indifference to this world, Thomas Berry argues that a transcendental God has unintentionally resulted in desacralizing the world, while the belief in redemption has exempted believers from assuming full responsibility for their actions (Appolloni 2015). 
The last argument (on the sacred indifference towards the secular) has only gathered force with the planet's current ecological unraveling. Growing evidence in climatology, geology, biology, and archeology suggests that humans have ushered the Earth into a new era, the Anthropocene, the first to be defined by the human footprint (Ceballos et al. 2015; Head 2014; Waters et al. 2016). Interpretations of its beginning vary widely, spanning from the human mastery of fire 400,000 years ago to the Holocene 10,000 years ago, to the Industrial Revolution in modern times and to the explosion of nuclear bombs in Hiroshima and Nagasaki at the end of the Second World War. Contrary to the uncertainty about the Anthropocene's inception, the dramatic J-shaped spike in resource extraction and anthropogenic environmental degradation during the last fifty years, what scholars call the "Great Acceleration," has called concerted attention to-and caused trepidation about-the future of the Earth and humanity (Steffen et al. 2015). Calls for human planetary stewardship to redress this catastrophic course have made their forceful appearance among natural scientists (Steffen et al. 2007). However, with the proliferation of scientific models of the Earth's periled future in public and academic discourse, both scientific and religious debates have often renewed a sense of crisis and adopted an apocalyptic tone (Hulme 2009; Webster 2013). Such a tone, scholars have argued, has reinforced a religious sense of detachment from earthly matters (Barker and Bearce 2013).

These discussions advance a new articulation of the well-established claim among scholars of millenarian denominations, which has long contended-well before the advent of the 'Anthropocene' - that the belief of the end of the world produces resignation and indifference about the state of the world (Johns 2016; Maier 2010). This article tries to complicate this understanding. I conducted over two years of ethnographic fieldwork on emerging forms of environmentalism in the face of ecological degradation on the Galápagos Islands, Ecuador. One of the twenty-four provinces of Ecuador, the Galápagos Islands consist of thirteen major islands (greater than $10 \mathrm{~km}^{2}$ ), six small islands (less than $10 \mathrm{~km}^{2}$ ), and over one hundred rocks and islets. My broader research studies how a variety of social actors on the islands cares for species and landscapes that are almost exclusively controlled by the Galápagos National Park. Here, I question the pervasive scholarly understanding that today's environmental unraveling justifies, or even engenders, cynicism towards the Earth by presenting a type of incipient environmental care that is religiously motivated. This essay revolves around a member, Celia, who sells endemic plants that she rescues from urban construction sites. Through her story, I argue that, on the Galápagos, the Jehovah's Witnesses' religiosity has inspired a vibrant form of environmentalism. To be sure, Celia's case does not reflect the Jehovah's Witnesses official doctrine nor the sensibility of all members of this denomination on the islands, let alone elsewhere. ${ }^{1}$ However, it illustrates a form of environmentalism that I have found among several Jehovah's Witnesses because of their religious convictions. In the conclusion, I take this form of care as an inspiration to rethink dominant scholarly analyses on the relationship between religion and the environment in a time of crisis.

Detailing Celia's environmental concerns and her attempts to remediate, I demonstrate that the Jehovah's Witnesses' vision of the ultimate future has the capacity to inform action rather than despair-contrary to what is often assumed about millenarian beliefs. If Christian theology has long drawn on the end of the world to cast dark futures, and if feminist and eco-theology have argued instead for eschatological hope (for nonetheless unspecified future scenarios), I show eschatology for its present affordances and capacities. Further, I highlight the significance of Celia's work as a mode of coexistence with other species that is an alternative to conservation. Political ecologists, geographers, and anthropologists are showing how appropriation of resources and land to the detriment of local people in the Global South is increasingly motivated by not only economic reasons (such as agribusiness), but also environmental ones-thus giving rise to forms of so-called "green grabs" (Fairhead et al. 2012). On the Galápagos, this approach has manifested itself with the establishment of

1 To the author's knowledge, there is no literature on forms of environmentalism among Jehovah's Witnesses. 
the Galápagos National Park in 1959, which covers almost 97\% of the islands and relegates the islands residents outside the park's borders, in the remaining 3\%. In the past decades, the alliance between local conservation institutions and international environmental agencies has further consolidated, resulting in a sustained marginalization of locals' voices (Parque Nacional Galápagos 2014). As evident on the Galápagos and in other protected areas, however, the power of conservation rests not only on resource or land appropriation, but also on forms of environmental governance that rely exclusively on experts and techno-scientific interventions, while marginalizing the needs and knowledge of local inhabitants (Crist 2013). Concerns about the environment in the time of the Anthropocene, which on the Galápagos motivate policies focused on protecting endemic species from the looming threat of extinction, have furthered increased the divide between locals and conservationists (Bocci 2017). In contrast, Celia and her friends bring native plants to a community that is otherwise removed from the local flora and the islands' environment in general. They thereby challenge the separation of nature and culture that Anthropocene discourse (and the conservation measures that address it) at once challenges and, in its renewed focus on the human, reinstates (Haraway 2015). Although unofficial, the Jehovah's Witnesses' form of religious environmentalism I describe below offers a novel approach to modes of "saving nature" of salient importance, showing how the faith and fate of the world are indissolubly entwined.

A final note about methodology: during my fieldwork, I quickly realized the intimate nature of a set of beliefs cultivated in practices rather than proclaimed in sermons. Opting for positivist methodologies in social science research such as distributing surveys, leading group discussions, or conducting interviews would have likely silenced beliefs and practices among people with very limited social capital on the islands. Given these considerations, I decided instead to share time with Jehovah's Witness members, to listen to their concerns, and to let discussions about theology and environmentalism emerge organically, that is, in the daily life and thanks to a mutual feeling of trust we were able to establish over time.

\section{Toward the Paradise (on a Construction Site)}

Heading to the outskirts of sprawling Puerto Ayora, the only city on the Galápagos Islands, to a denuded area soon to become a new neighborhood, Celia was, in fact, going to work. The municipality had recently swapped land with the bordering national park, ceding rocky coastal terrains in exchange for an area north of the city's current limit. I accompanied Celia to the new site on the back of a motorcycle that she drove confidently along the new dirt roads, anticipating bumps and avoiding pits. Her goal was to save endemic plants from their inevitable death when the digging of foundations, the erection of houses, the installation of the electric and water grids, and the paving of roads commenced. Later, she would use those plants to arrange endemic gardens outside hotels or state institutions.

The landscape looked desolate. Large lots lay cleared, and piles of earth accumulated at the intersections of gravel roads. In the process, construction workers had leveled much of the vegetation, including rare plant species. The same fate awaited the remaining vegetation. Although depressing, for Celia it was not surprising. She had lived on the Galápagos Islands for three decades and witnessed the dramatic increase in urbanization over time. Once an exclusive tourist destination for a few private yachts, the Galápagos began at the beginning of the 1990s to attract more tourists and, in turn, mainland Ecuadorians seeking work. Celia and her family were among those migrants. Since then, the number of Galápagos residents has grown from around 9000 in the 1980s to around 30,000 today. The expansion of Puerto Ayora, which we had just left, was a prominent sign of the growth in tourism and the human population. Roaring in the background with traffic and construction noise, the city looked like a sea whose edge was swelling and growing, preparing to roll forward another wave of construction on the future neighborhood north of the bay, where we were standing (see Figure 1). 


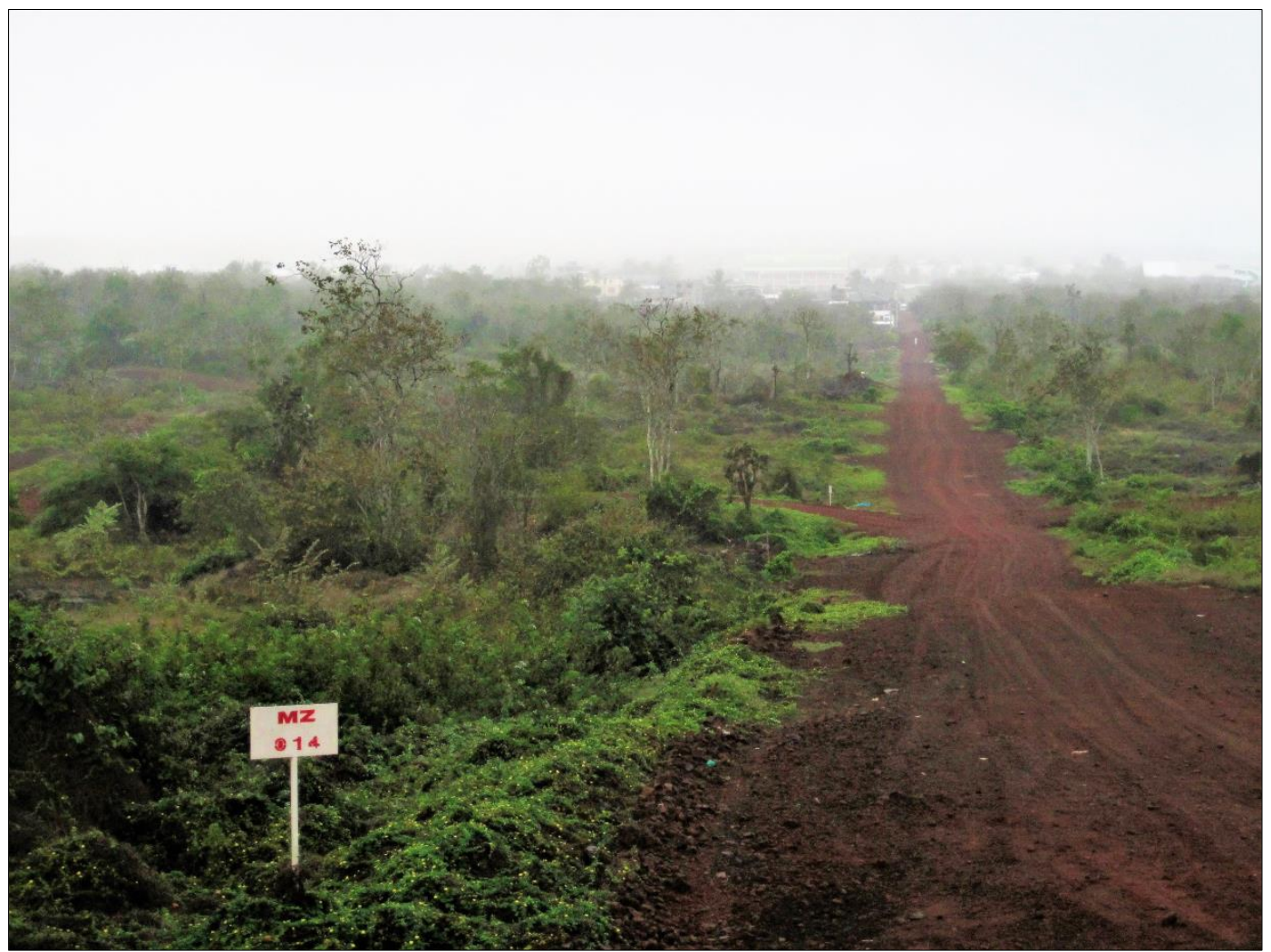

Figure 1. El Mirador, 2013. Photo by author.

There, according to the municipal plan, nature would turn into city. Yet the inexorable reclamation of the territory, from spiny bushes, arid terrains, and solitary trees to an imbroglio of streets and buildings, would take place gradually. Despite plans for massive construction, with multistory houses and incredibly narrow streets, as in the previous new neighborhood of La Cascada, we could see only the most superficial outline of the future interventions. Dirt roads met at squared intersections; orange-tipped signposts tentatively delimited future lots and properties. Though not yet human-dominated, the area-with bulldozed land and cleared vegetation-was neither the type of human-less landscape of the Galápagos National Park's lowlands. Before our eyes, the new neighborhood El Mirador presented itself as a strange interregnum: it stood as the new, ever-expanding membrane between the city and the larger geography of the bay and the rising hills behind it, mostly protected areas belonging to the park. Also, it operated as a transition between two temporal domains: from a people-less past to its human-inhabited future. That day, however, did not belong to either. Celia was taking advantage of the time lag between the design of the new neighborhood and its implementation to offer preemptive remediation to a sample of the endemic plants that would be obliterated. We walked undisturbed among rocks and plants, in the fleeting moment before their irreversible reconfiguration.

Celia needed endemic cacti (Opuntia galapageia) for a garden she had been commissioned to create. With her assistant, Luisa, they carved a little circle of dirt around the plant to avoid severing its roots. Using small squares of cardboard, they carefully uprooted each small cactus and put them in the boxes hanging to each side of their motorcycles (see Figure 2). To test my confidence as I prepared to help, Celia told me with a sardonic smile that, once past the initial discomfort, the cacti's spines would eventually stop hurting me and start talking to me. Luisa, perhaps not new to the joke, simply looked at her punctured and seemingly permanently swollen hands and prepared to work. 


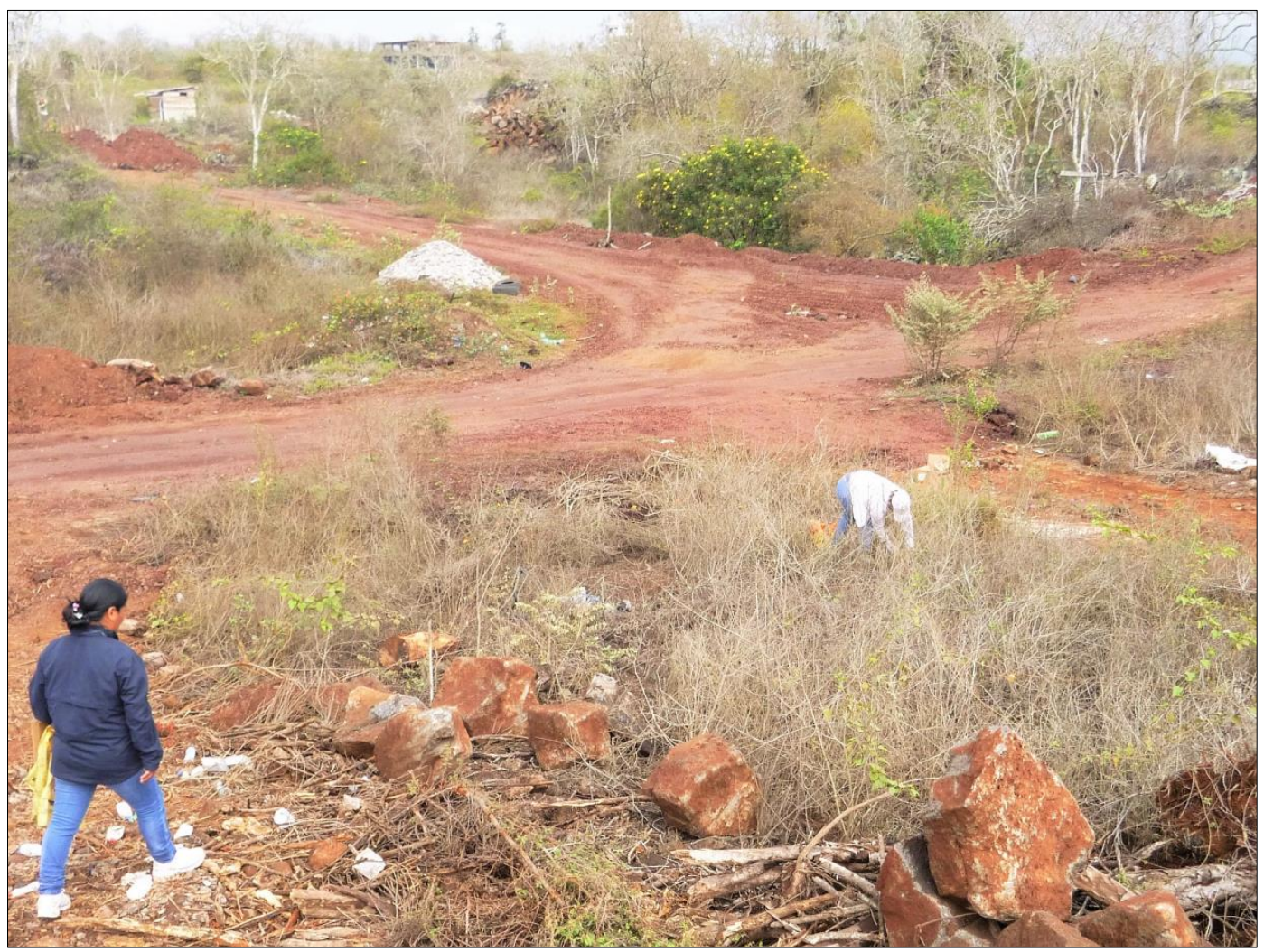

Figure 2. Celia and Luisa. Photo by author.

Juvenile cacti were few and far between. For Celia, their discovery triggered many joys: being able to later install them in her gardens and having found them alive in a time of rapid ecological change-after the spread of invasive species and before the new wave of urbanization. The cacti we found were survivors of present and past, and of human and non-human ecological deterioration. For Celia, though, the joy to salvage endangered plants had, above all, a markedly religious significance. A longtime Jehovah's Witness, Celia interprets the widespread degradation as a sign of the approaching end of the world. But, in perhaps surprising ways, the same understanding motivates her to act, rather than to desist. As she stood and dusted off her pants, she looked at the small cactus she had just uprooted and was carefully holding like an unfledged bird. Sotto voce, her breath blending with the wind, Celia uttered: "we already know that, by doing this, we head to the paradise."

\section{Endemicity, Extinction, Restoration}

The Galápagos archipelago is remote geographically: it straddles the equator $1126 \mathrm{~km}$ from the westernmost point of mainland Ecuador. It is also remote geologically, as all of its islands surfaced from the ocean as a result of volcanic eruptions that occurred between 1 and 5 million years ago, with no previous contact with the continent (Grehan 2001). As a result, species have reached the Galápagos, drifting on logs or swept by westward winds, at a rate of one species per 10,000 years and subsequently evolved in isolation from mainland ecosystems. Humans have inhabited the Galápagos for only a fraction of the archipelago's geological time: there was no indigenous human population, and the islands were discovered late (in 1553) and permanently colonized even later (in the 1830s) (Latorre 1999).

Minuscule in size relative to the world, the Galápagos nevertheless enjoy a special significance for natural sciences, conservation, and tourism across the globe because of their unique species. Further, Darwin's visit and its relevance in his later elaboration of the theory of evolution (Sulloway 1982) have conferred to these islands a worldwide, everlasting allure. Citing the uniqueness of species and the 
high degree of ecosystem preservation, UNESCO designated the Galápagos a World Heritage Site in 1978. Forty years later, however, growth of tourism, immigration, and invasive species has affected local ecosystems and species in alarming ways. In 2007, UNESCO responded by adding the Galápagos to the list of World Heritage Sites in Danger. During the past two decades, the annual number of tourists has increased more than four-fold, with current estimates surpassing the 200,000 mark (Instituto Nacional de Estadística y Censos 2017). With more goods and people moving from the continent, new species also have come to the islands, and a minority of them has become invasive. Ecologists estimate that invasive species constitute the single most serious threat to the Galápagos' ecosystems (Atkinson et al. 2012). Due to the islands' remoteness, the Galápagos' endemic species have evolved with inadequate defense mechanisms from mainland species. Some newly arrived species have proved superior to endemic species, both physiologically (in matters of nutrition and growth rate) and ecologically (through competition and distribution), and have thrived in their new habitat. Currently, the number of introduced vascular plants has surpassed endemic ones: 748 vs. $\sim 500$ (Tye 2006).

These figures reflect worrisome global trends. Invasive species pose the greatest threat to terrestrial ecosystems worldwide (Charles and Dukes 2008). Consequently, $60 \%$ of all endemic plants are listed as endangered by the International Union of Conservation of Nature (IUCN). Islands are the unfortunate loci for this story, both in the past and in its current acceleration. Islands represent $5 \%$ of the Earth's land mass, but they have been the site of $80 \%$ of the known extinctions since 1500 (Island Conservation 2017). Islands are also expected to be the hardest hit according to estimates indicating the exponential increase of the global extinction rate (Ceballos et al. 2015; Island Conservation 2017). Introducing concepts such as the "homogocene," ecologists have decried the increasingly less diverse biota as a sign of the dulling of nature's vibrancy (Olden et al. 2018). As part of the ever-expanding human footprint on our planet, species that humans introduce and take over (or those that we fail to keep alive) add to the Anthropocene argument: humans have become the main actor of ecological change.

Because of its rocky terrain and isolation, the Galápagos' tally of species, what ecologists call "biodiversity richness," is lower than in lush continental ecosystems such as the Amazon. Yet these same features have allowed the unfolding of distinct evolutionary lines on the archipelago. What is remarkable about the Galápagos' biodiversity, then, is its uniqueness rather than abundance. In such a context of distilled ecological scarcity, each species counts. And, conversely, the threat of extinction to each species matters a great deal, too. To prevent extinction, the park and other conservation organizations have in recent years doubled down on projects protecting "pristine nature" from the local people. In one project, dedicated to cataloguing endemic flora, Celia learned the name and characteristics of many endemic plants while working for the Charles Darwin Foundation, the Galápagos' largest scientific research organization. But, at the end of the project, she found herself dissatisfied with its conservation approach, which left little room for the local population's involvement.

She quit and started her own business creating "endemic gardens." Her company is unique on the islands, and she is immensely proud of it. Private owners and government building directors who request her service have done so largely as green branding, indicating their support of conservation-minded projects that protect the islands' fragile ecosystems. Through her business, Celia values those plants beyond their worth in the Galápagos' tourist economy. Learning about plants gave her an appreciation of the local ecosystems and a motivation to respond directly to their profound changes, without depending on conservation projects. Yet, above all, through her job Celia makes sure to be a good Witness.

\section{Back to the Field}

"Look at this plant," she said that day in El Mirador. Talkative and outgoing, Celia was teaching me about shrubs and flowers, native and invasive, that we encountered in the semi-arid terrain. I quickly learned that the causes of ecological degradation went beyond urbanization. While walking, 
Celia showed me plant species that had come from the mainland and spread without human help, some even suffocating endemic species. With increased flows of people and food between the islands and the outside, Celia had noticed the dramatic consequences of invasive species to the local ecosystems (Atkinson et al. 2012; Graham and Cruz 2007). Little by little, the site was reconfigured into a complex herbarium of plants, some in danger and others taking over. Celia identified each plant species by noting the color of a flower, scrolling her finger around the serrated indentation of a leaf, or pointing to the pattern of encroachment of a new invasive bush. With patience, she invited me into an understanding of composite plant assemblages that came through all senses: the hues of flowers, the olfactory quality of pistils, the rustle of wind through thickets and bushes, the dust that tickled our throat coming from the newly exposed soil. As we examined plants and, through them, the profound changes on the islands, joys and worries became suspended in those focused moments of synesthetic encounters (see Figure 3).

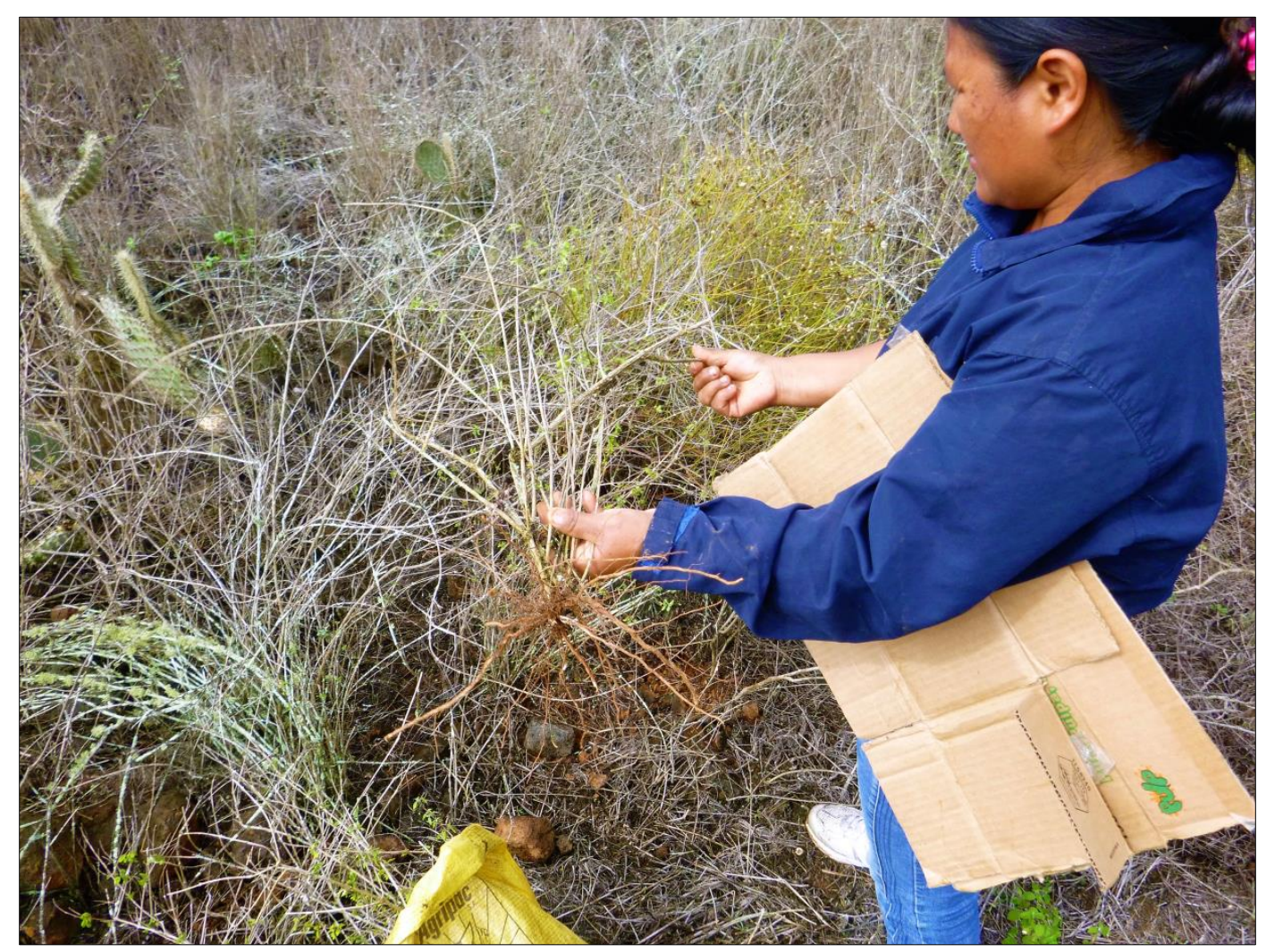

Figure 3. Parsing species. Photo by author.

"Look at this plant," she told me, as she cupped a crown of small white flowers jutting bright yellow pistils. Of the Verbenaceae family, Lantana camara is an ornamental species; it is also, due to its extraordinary adaptability for reproduction in a wide range of altitudes, sunlight exposure, and soil condition, a weed. The first experiments ever attempted at deploying an insect to eradicate a weed (called "biological control") took place at the turn of the 20th century and targeted Lantana camara. Yet that attempt, and all those that ensued, failed. Lantana camara has continued to spread across tropical and subtropical regions in the Americas, including to the Galápagos in 1986 (Rentería Bustamante and Ellison 2004). As we stood at the edge of a lot, Celia pointed to horizontal stems of Lantana already reaching into the area newly cleared of vegetation.

Lantana camara seeds had taken advantage of urbanization and established new sites in the archipelago and, from there, moved to even more sites. While a consequence of human pressure on the Galápagos' ecosystems, invasive species such as Lantana also amplify anthropogenic change: they reduce the abundance of endemic plants and adversely affect the nesting habit of endangered 
avian species endemic to the Galápagos, such as the dark-rumped petrel (Rentería Bustamante and Ellison 2004). In El Mirador, the newly denuded terrain was accelerating the spread of Lantana. But, with or without the "help" of urbanization, Lantana's spread was impossible to stop. Celia saw this as a sign of the accelerating degeneration of the human and natural fabric of the Earth-the end of the world. Aware that she could not reverse its course, she was nevertheless busy collecting the imperiled endemic plants. By uprooting cacti, she was determined to give them a second chance in a new home elsewhere: "When the paradise comes, these plants will be already there." Her vision of a terrestrial paradise colors her hopeful anticipation of the future and governs her actions in the present. As much as she could, she salvages plants that the establishment of the paradise will glorify through its ecological restitution (see Figure 4). "You need to work towards the paradise," she told me with conviction. She smiled as she declared, "I'm planting the seeds of the future" ("estoy sembrando las semillas del futuro").

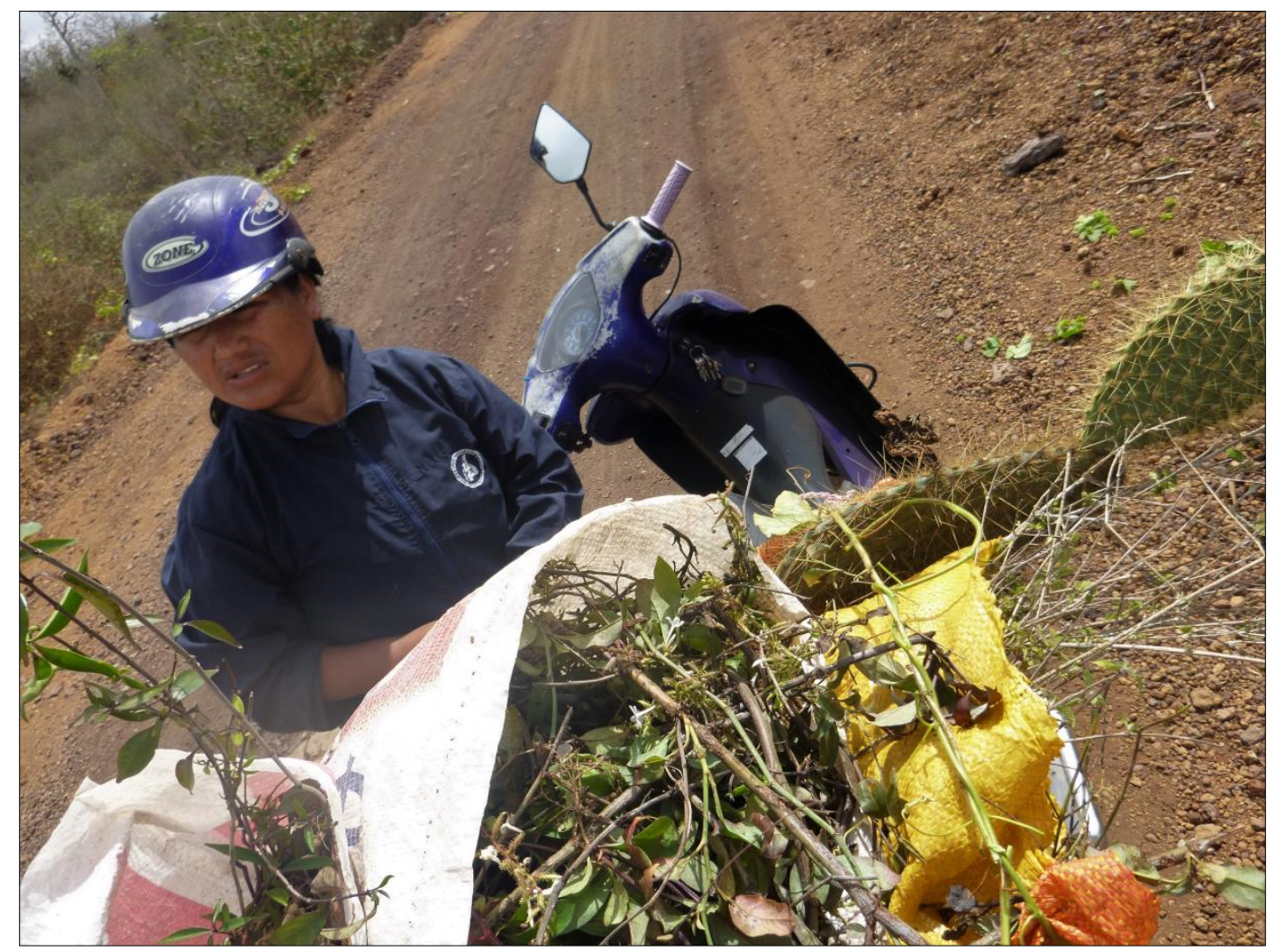

Figure 4. The harvest. Photo by author.

The future she intimated and, eyes gazing intently beyond the horizon, invited me to see, was the one after the Judgment Day. For the Jehovah's Witnesses, there is neither hell nor a celestial paradise but, rather, a restored Earth. ${ }^{2}$ Until then, Celia and her fellow Witnesses expect a worsening of human and natural conditions. Continuing to walk and look for cacti, she admonished: "Jehovah will destroy those who destroy the Earth; it's written." She was referencing to a passage in Revelation that we had read days before at her house: "And the nations were angry, and thy wrath is come, and [ ... ] that thou shouldest give reward unto thy servants the prophets [ ... ] and shouldest destroy them which destroy the earth" (11:18).

2 The Jehovah's Witness doctrine establishes that, aside from a fixed number of people who will ascend to the sky (which is already full), the remaining members will live in the eternal paradise on earth. 
An exception among Christian millenarian denominations, though consistent with early Christian eschatology (Wright 2008), the Jehovah's Witnesses believe that the paradise will be on earth. Celia had in mind, and was acting towards, that form of terrestrial restoration that her religion promises. Informed by this belief, Celia salvages endangered species to prepare for divine restoration. To be sure, her botanical knowledge and field experience shape her determination to save each individual endemic plant from the threats of urbanization and invasive species. However, her justification is ultimately religious; in fact, her passion for rescuing endemic plants articulates her religious beliefs. The promise of a terrestrial restoration by divine intervention motivates local Jehovah's Witness members like Celia to "plant the seeds" of that future. While Celia registers environmental degradation as a sign of the impending end of the world, her work is a form of, in her words, "acting towards" the terrestrial restoration that the paradise will realize.

Religious scholars have often interpreted millenarian beliefs such as Celia's as leading to uninterest in the mundane aspects of life. Crucial in this widespread interpretation of Christian millenarian eschatology is its marked pessimistic register (Johns 2016). In the case of the Jehovah's Witnesses, however, whereas their reading of the current human and natural affairs is negative, it is dispassionate but does not lead to pessimism. Rather, it confirms that their religious understanding is correct. Further, if applied on the Galápagos, the conventional theory misses the crucial role of the terrestrial paradise in the Jehovah's Witnesses' understanding of, and intervention in, the present state of the affairs. Not simply eschewing pessimism, Celia and other Jehovah's Witnesses cultivate modes of religious ecological hope. Continuing to work, Celia went on with our conversation: "Remember Psalms 37, that we will inherit the Earth forever. " ${ }^{3}$ Everything will turn back to its original place, humans and animals," she continued. "And the introduced species?" I asked. She replied calmly, "Everything will return to its natural state, as Isaiah says" ("The wolf and the lamb shall feed together, and the lion shall eat straw like the bullock: and dust shall be the serpent's meat. They shall not hurt nor destroy in all my holy mountain" 65,25$)$.

\section{Eschatology, Now}

In his analysis of the Jehovah's Witnesses, sociologist Andrew Holden contends that "the belief in the imminence of the end of time as we know it prevents [the Jehovah's Witnesses] from making advanced plans for the future" (Holden 2002, p. 98). Thus, pessimism about the present state of affairs precludes believers from either fully participating in the present or planning for a secular, near-term future, keeping instead their focus on the post-apocalyptic domain. "The Witnesses," continues Holden, "are prevented by their own doctrine from romanticizing the past and the present, but they do romanticize the future" (Holden 2002, p. 36). However, this position fails to understand that, for Jehovah's Witnesses such as Celia, the "end of time" in fact blends into a vision of a restored future that calls for action, participation, and responsibility in the present. The "end of time" of Revelation is not an end in absolute terms, but a threshold that marks the end of time as a finite domain. In this essay, I have taken the latter observation a step further and asked how these "romanticized" visions of the future inform today's awareness of, and actions within, a changing environment.

A more positive and Earth-centered vision of the future is not the exclusive prerogative of the Jehovah's Witnesses on the Galápagos. Christian feminist and eco-theologians have articulated eschatological interpretations aimed to "correct [the] tendency to discount this life on Earth in favor of an afterlife" (Keller 2007, p. 13; see also Mercer 2017). Seeking concrete responses to urgent issues such as gender, indigenous, and nature's rights abuses, these theological currents have refused a reading of the end of time as damning or as justifying detachment. Rossing, notably, expands on the usual translation of eschathos ("end") to signify "brink" and "edge" and asserts that the Anthropocene

3 "The righteous shall inherit the land, and dwell therein forever." The end of the world will in fact be the beginning of a new one." Psalms 37:29. 
constitutes an instantiation of eschatos, or edge, for humanity and the Earth. With this premise, Rossing resists what she calls "escapist eschatological thinking" (termed "heavenism" by Habel and Balabanski 2002), which focuses only on the afterlife. Instead, she argues that eschatology matters because it "gives people a sense of hope for the future" (Rossing 2017, p. 328). Similarly, Mercer reflects on the etymology of witnessing (martyria) as "both accompaniment and acknowledgment" as the practice that "can produce the possibility of change" (Mercer 2017, p. 288). Lastly, Keller aims to reclaim eschatological hope from the strictures of "a nature-transcending and patriarchal God" (Keller 2015, p. 11) and insists on the not-yet-known possibilities that arise from relating with others, which she calls "apophatic entanglement" (Keller 2014, p. 7; see also Bauman 2015).

Yet it is this very longing for the future, optimistic though it may be, that is often confined to the realms of possibility and can thus cultivate a sense of detachment for the present. For Celia, rather, the promise of a restored Earth in the future reverberates back in time, to the present. Theological proposals for an optimistic eschatology often fall short of articulating the possibility for actions in the here and now. Instead, the future for Celia operates as responsibility as well as a template for action. I draw on the practical commitment of feminist theology that reclaims experience as a theologically relevant domain (Mercer 2017; Radford 2017; Jenkins 2013; Ruether 1996) to challenge intellectualist approaches that absolve religiosity from taking responsibility in the present. Further, I let ethnographic sensibility inform my analysis to arrive at the understanding of Celia's practice as a form of worldand faith-making: she participates in the urban landscape as well as in the Jehovah's Witness theology.

\section{Conclusions: Continuous Time}

Back at her shop, we carefully removed the cactuses and placed them in small plastic bags with fresh soil (see Figure 5). We then arranged them among other endemic plants that Celia and Luisa had previously collected: Scalesia affinis, Lecocarpus de Darwin, and Lantana peduncularis. For both of us, the thoughts that our discussion about the paradise had incited still lingered. "Sometimes," she finally said, breaking that full, absorbed silence, "I think about Santa Cruz, how it will be then [during the terrestrial paradise]. I imagine rivers flowing, the vegetation abundant and lush, the mangroves covering all the shores ... " During the last three decades, her city, Puerto Ayora, has used all the sand and gravel along the bay for construction. The small beach and the mangroves have vanished as a result. Instead, the shoreline is covered by hotels and restaurants. Though occluding the vista, those buildings are transparent signs of something else: to Celia and other Jehovah's Witnesses, they confirm the entwinement of human and ecological degradation. With the paradise, the mangroves and the rich habitats they sustain will return and flourish again. Her mention of rivers flowing was more puzzling. Santa Cruz, which is of basaltic lithic formation, does not have permanent streams or creeks-how could rivers flow? Celia later explained her vision: over continuous time, the rainwater will build reservoirs in the uplands, which will stream downhill and carve novel, permanent watercourses. Time, then, will continue to flow, as the paradise will announce itself by establishing a terrestrial restoration. As scholars of the Anthropocene argue, the end of the secular time is in fact a critical edge, which invites response rather than despair.

With her charisma, Celia has convinced other Jehovah's Witness members to do similar work. They give Celia endangered plants from amidst the crops on their farms, or they join Celia in her shop after work, as I did that day. Further, Celia's commitment was contagious, and it touched my thinking too. Indeed, the significance of Jehovah's Witnesses' environmentalism extends beyond not only Celia but also the Galápagos. The secular world had long dismissed religious preoccupations about the end of the world as an issue of marginal significance (Waddell 2014); today, the current planetary ecological crisis has renewed similar sentiments (Masco 2016). What would it mean for activists, anthropologists, ecologists, and religious scholars to take the Jehovah's Witnesses' future-oriented action seriously in thinking about the Anthropocene? If the presented case of Celia and her friends may not be important numerically, I discuss it in this essay for its relevance in provoking this question. 


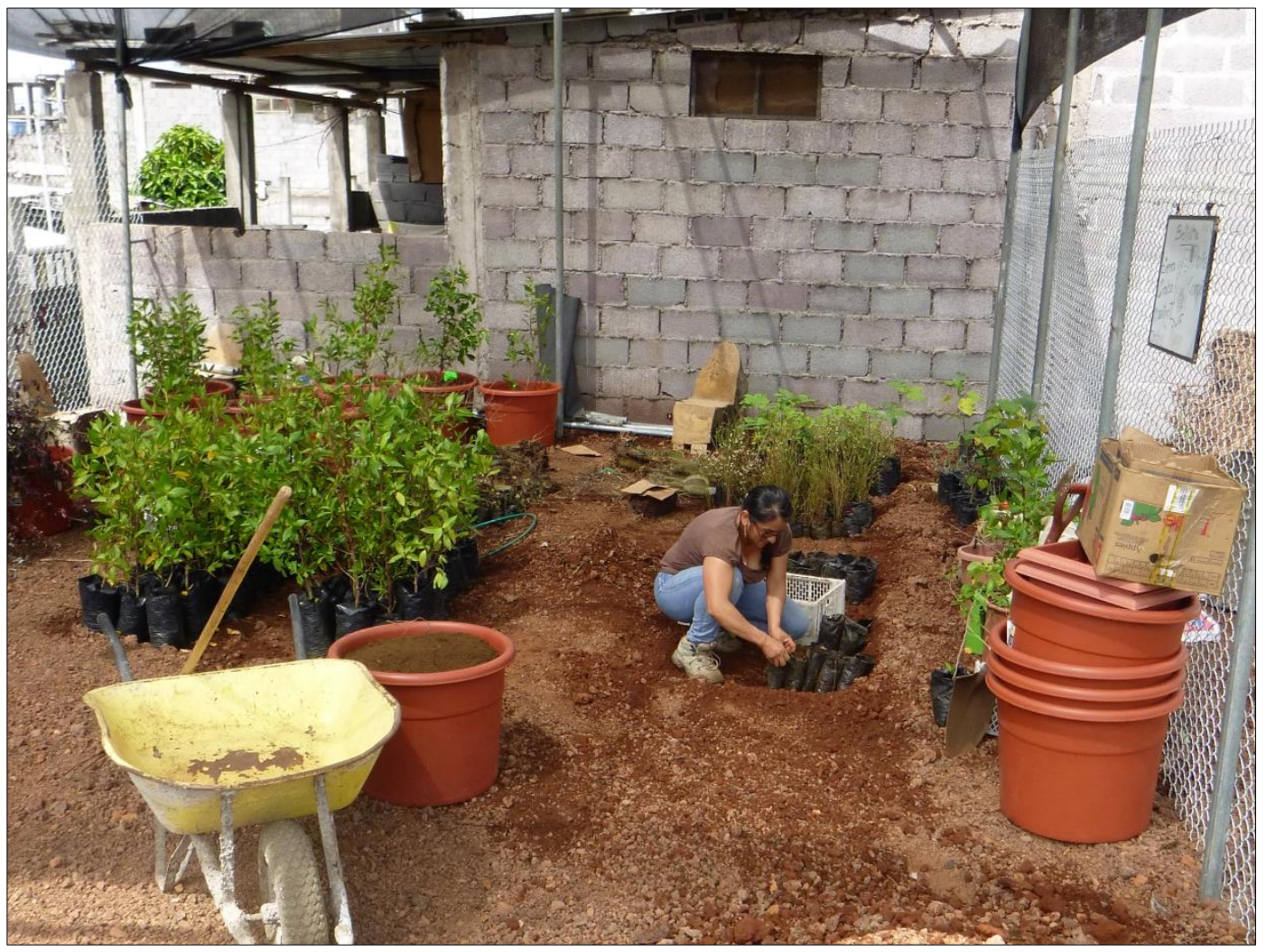

Figure 5. The shop. Photo by author.

While discussions about reconciling eschatology and environmentalism are ongoing, there is often the tendency, sometimes even deliberate strategy, to couch this conversation in anthropocentric terms, that is, by orbiting nature's worth around human values and needs (Fisher 2018). In contrast, the long temporality and earth-centric vision of religious environmentalism brings back a decidedly biocentric sensibility - the longing for, and action toward, a restored earth, where humans are but one of the participants in it. Further, to recognize non-secular, non-Western actors means to argue for the redistribution of agency (over making theology too) between the first world and the Global South, thus recalibrating the decidedly Western understanding of the Anthropocene. Reasons for this latter move are both practical and theoretical. There is growing evidence that the most vulnerable suffer the most from climate change and will continue to do so with the exacerbation of the environmental crisis. In the Anthropocene's optics, concerns about dystopian ecological futures are more than ever pervasive and justified. And yet, such concerns have often reinforced conservation approaches based on expert-driven knowledge that tend to exclude the involvement of local populations (Crist 2013). Excluding local residents and alternative interpretations of the ecological crisis informed by their religious views deprives conservation on the Galápagos of a potent ally. Additionally, if scholars are thinking with the Anthropocene to ultimately dismantle the human/nature divide (Chakrabarty 2016), part of this project must also challenge the sacred/secular dichotomy-which confines the sacred to the subaltern pole (Bubandt 2018). If, as many have noted, the crisis of the Anthropocene is a narrative crisis (Rossing 2017, p. 328; see also Ghosh 2016), then we need as many resources and stories to address it.

On the Galápagos, the ecological care that local Jehovah's Witnesses enact offers an alternative to the conservationists' approach to current ecological degradation. By presenting subjects that, practically and intellectually, are usually absent in the discourse of the Anthropocene, this essay demonstrates that responses to ecological crises do not univocally lead to apolitical, large-scale, scientific models of worrisome futures and increased reliance on technological solutions. Instead, Jehovah's Witnesses are responding to ecological changes with actions that are gendered, collective, and committed to 
the well-being of other species; these actions renew, rather than relinquish, ethical commitments and practical responses vis-à-vis troubled ecological times.

Funding: This research received no external funding.

Acknowledgments: I presented an early draft of this article at the workshop "Being Human in the Age of Humans: Perspectives from Religion and Ethics" funded by Humanities Without Walls consortium. Thanks to all the participants for their comments and suggestions.

Conflicts of Interest: The author declares no conflict of interest

\section{References}

Appolloni, Simon. 2015. The Roman Catholic Tradition in Conversation with Thomas Berry's Fourfold Wisdom. Religions 6: 794-818. [CrossRef]

Atkinson, Rachel, Marc Gardener, and Victor Carrion. 2012. Fifty Years of Eradication as a Conservation Tool in Galápagos: What Are the Limits. In The Role of Science for Conservation. Abingdon: Routledge, pp. 183-98.

Barker, David, and David Bearce. 2013. End-Times Theology, the Shadow of the Future, and Public Resistance to Addressing Global Climate Change. Political Research Quartely 66: 267-79. [CrossRef]

Bauman, Whitney A. 2015. Climate Weirding and Queering Nature: Getting Beyond the Anthropocene. Religions 6: 742-54. [CrossRef]

Bocci, Paolo. 2017. Tangles of Care: Killing Goats to Save Tortoises on the Galápagos Islands. Cultural Anthropology 32: 424-49. [CrossRef]

Bubandt, Nils. 2018. A Non-Secular Anthropocene: Spirits, Specters and Other Nonhumans in a Time of Environmental Change. More-Than-Human. AURA Working Papers. Aarhus: Aarhus University, vol. 3.

Ceballos, Gerardo, Paul R. Ehrlich, Anthony D. Barnosky, Andrés García, Robert M. Pringle, and Todd M. Palmer. 2015. Accelerated Modern Human-Induced Species Losses: Entering the Sixth Mass Extinction. Science Advances 1: e1400253. [CrossRef] [PubMed]

Chakrabarty, Dipesh. 2016. Humanities in the Anthropocene: The Crisis of an Enduring Kantian Fable. New Literary History 47: 377-97. [CrossRef]

Charles, Heather, and Jeffrey S. Dukes. 2008. Impacts of Invasive Species on Ecosystem Services. In Biological Invasions. Edited by Wolfgang Nentwig. Ecological Studies 193. Berlin and Heidelberg: Springer, pp. 217-37. [CrossRef]

Crist, Eileen. 2013. On the Poverty of Our Nomenclature. Environmental Humanities, November 3. Available online: http:/ / environmentalhumanities.org/2013/11/03/provoked-discussion-on-the-poverty-of-ournomenclature/ (accessed on 4 March 2016).

Fairhead, James, Melissa Leach, and Ian Scoones. 2012. Green grabbing: A new appropriation of nature? Journal of Peasant Studies 39: 237-61. [CrossRef]

Fisher, Chelsea. 2018. Towards a Dialogue of Sustainable Agriculture and End-Times Theology in the United States: Insights from the Historical Ecology of Nineteenth Century Millennial Communes. Agricultre and Human Values 35: 791-807. [CrossRef]

Ghosh, Amitav. 2016. The Great Derangement: Climate Change and the Unthinkable. Chicago: University of Chicago Press.

Graham, Watkins, and Felipe Cruz. 2007. 'Galápagos at Risk.' A Socioeconomic Analysis. Galápagos: Charles Darwin Foundation.

Grehan, John. 2001. Biogeography and Evolution of the Galápagos: Integration of the Biological and Geological Evidence. Biological Journal of the Linnean Society 74: 267-87. [CrossRef]

Grim, John, and Mary Evelyn Tucker. 2014. Ecology and Religion. Washington, DC: Island Press.

Habel, Norman, and Vicky Balabanski. 2002. Ecojustice Hermeneutics: Reflections and Challenges. In Earth Bible. Sheffield: Sheffield Academic Press.

Haraway, Donna. 2015. Anthropocene, Capitalocene, Plantationocene, Chthulucene: Making Kin. Environmental Humanities 6: 159-65. [CrossRef]

Head, Lesley. 2014. Contingencies of the Anthropocene: Lessons from the 'Neolithic'. The Anthropocene Review 1: 113-25. [CrossRef] 
Holden, Andrew. 2002. Jehovah's Witnesses: Portrait of a Contemporary Religious Movement. London: Psychology Press.

Hulme, Mike. 2009. Why We Disagree about Climate Change: Understanding Controversy, Inaction and Opportunity. Cambridge: Cambridge University Press.

Instituto Nacional de Estadística y Censos. 2017. Galápagos Tiene 25.244 Habitantes Según Censo 2015. Available online: http: / www.ecuadorencifras.gob.ec/Gal\%C3\%A1pagos-tiene-25-244-habitantes-segun-censo-2015/ (accessed on 28 May 2018).

Island Conservation. 2017. Why Islands. Island Conservation (blog). Available online: https://www. islandconservation.org/why-islands/ (accessed on 11 April 2017).

Jenkins, Willis. 2013. Ecologies of Grace: Environmental Ethics and Christian Theology. Oxford: Oxford University Press.

Johns, Loren. 2016. The Apocalypse of John and Theological Ecosystems of Destruction and Escape. In Rooted and Grounded: Essays on Land and Christian Discipleship. Eugene: Pickwick.

Keller, Catherine. 2007. Eschatology, Ecology and a Green Ecumenacy. Journal for the Study of Religion, Nature and Culture 1: 84-99. [CrossRef]

Keller, Catherine. 2014. Cloud of the Impossible: Negative Theology and Planetary Entanglement. New York: Columbia University Press.

Keller, Catherine. 2015. A Democracy of Fellow Creatures. Studia Theologica-Nordic Journal of Theology 69: 3-18. [CrossRef]

Latorre, Octavio. 1999. El hombre en las Islas Encantadas: la historia humana de Galápagos. Porto Seguro: O. Latorre.

Maier, Harry. 2010. Green Milleniarism: American Evangelicals, Environmentalism and the Book of Revelation. In Ecological Hermeneutics: Biblical, Historical and Theological Perspectives. London: Bloomsbury Publishing.

Masco, Joseph. 2016. Catastrophe's Apocalypse. In The Time of Catastrophe: Multidisciplinary Approaches to the Age of Catastrophe. Abingdon: Routledge.

Mercer, Joyce. 2017. Environmental Activism in the Philippines: A Practical Theological Perspective. In Planetary Solidarity: Global Women's Voices on Christian Doctrine and Climate Justice. Minneapolis: Fortress Press.

Mickey, Sam. 2015. Whole Earth Thinking and Planetary Coexistence: Ecological Wisdom at the Intersection of Religion, Ecology, and Philosophy. Abingdon: Routledge. [CrossRef]

Notermans, Catrien, Albertina Nugteren, and Suma Sunny. 2016. The Changing Landscape of Sacred Groves in Kerala (India): A Critical View on the Role of Religion in Nature Conservation. Religions 7: 38. [CrossRef]

Olden, Julian D., Lise Comte, and Xingli Giam. 2018. The Homogocene: A Research Prospectus for the Study of Biotic Homogenisation. NeoBiota 37: 23-36. [CrossRef]

Palmer, Martin, and Victoria Finlay. 2003. Faith in Conservation: New Approaches to Religions and the Environment. Washington, DC: World Bank.

Parque Nacional Galápagos. 2014. Plan de Manejo de Las Areas Protegidas de Galápagos Para El Buen Vivir. Galápagos Islands: Parque Nacional Galápagos.

Radford, Clare Louise. 2017. Meaning in the Margins: Postcolonial Feminist Methodologies in Practical Theology. Practical Theology 10: 118-32. [CrossRef]

Rentería Bustamante, Jorge Luis, and Carol Ellison. 2004. Potential Biological Control of Lantana Camara in the Galápagos Using the Rust Puccinia Lantanae. SIDA, Contributions to Botany 21: 1009-17.

Ronan, Marisa. 2017. Religion and the Environment: Twenty-First Century American Evangelicalism and the Anthropocene. Humanities 6: 92. [CrossRef]

Rossing, Barbara. 2017. Reimagining Escathology toward Healing and Hope. In Planet Solidarity. Minneapolis: Fortress Press.

Ruether, Rosemary Radford. 1996. Women Healing Earth: Third World Women on Ecology, Feminism, and Religion. Ossining: Orbis Books.

Steffen, Will, Paul J. Crutzen, and John R. McNeill. 2007. The Anthropocene: Are Humans Now Overwhelming the Great Forces of Nature. AMBIO: A Journal of the Human Environment 36: 614-21. [CrossRef]

Steffen, Will, Wendy Broadgate, Lisa Deutsch, Owen Gaffney, and Cornelia Ludwig. 2015. The Trajectory of the Anthropocene: The Great Acceleration. The Anthropocene Review 2: 81-98. [CrossRef]

Sulloway, Frank J. 1982. Darwin and His Finches: The Evolution of a Legend. Journal of the History of Biology 15: 1-53. [CrossRef] 
Tye, Alan. 2006. Can We Infer Island Introduction and Naturalization Rates from Inventory Data? Evidence from Introduced Plants in Galápagos. Biological Invasions 8: 201-15. [CrossRef]

Waddell, Robby. 2014. A Green Apocalypse: Comparing Secular and Religious Eschatological Visions of the Earth. In Blood Cries Out: Pentecostals, Ecology, and the Groans of Creation. Eugene: Wipf and Stock Publishers.

Waters, Colin N., Jan Zalasiewicz, Colin Summerhayes, Anthony D. Barnosky, Clément Poirier, Agnieszka Gałuszka, Alejandro Cearreta, Matt Edgeworth, Erle C. Ellis, Michael Ellis, and et al. 2016. The Anthropocene Is Functionally and Stratigraphically Distinct from the Holocene. Science 351: aad2622. [CrossRef]

Webster, Joseph. 2013. The Eschatology of Global Warming in a Scottish Fishing Village. The Cambridge Journal of Anthropology 31: 68-84. [CrossRef]

Wright, Nicholas T. 2008. Surprised by Hope: Rethinking Heaven, the Resurrection, and the Mission of the Church. Grand Rapids: Zondervan.

C 2019 by the author. Licensee MDPI, Basel, Switzerland. This article is an open access article distributed under the terms and conditions of the Creative Commons Attribution (CC BY) license (http:// creativecommons.org/licenses/by/4.0/). 